\title{
Effects of anthropogenic and natural disturbance on a recently settled continental shelf flatfish
}

\author{
Mark C. Sullivan ${ }^{1, *}$, Robert K. Cowen ${ }^{1}$, Kenneth W. Able ${ }^{2}$, Michael P. Fahay ${ }^{3}$ \\ ${ }^{1}$ Rosenstiel School of Marine and Atmospheric Science, Division of Marine Biology and Fisheries, University of Miami, \\ 4600 Rickenbacker Causeway, Miami, Florida 33149, USA \\ ${ }^{2}$ Marine Field Station, Institute of Marine and Coastal Sciences, Rutgers University, 800 c/o 132 Great Bay Boulevard, \\ Tuckerton, New Jersey 08087, USA \\ ${ }^{3}$ National Marine Fisheries Service, Northeast Fisheries Science Center, James J. Howard Marine Sciences Laboratory, \\ 74 Magruder Road, Highlands, New Jersey 07732, USA
}

\begin{abstract}
Concern over essential fish habitat characterization and conservation has directed attention toward the potential impact of mobile fishing gear on benthic ecosystems. However, previous findings do not necessarily extend to all environments, life stages, and/or gear types. The juvenile stage of benthic marine fishes is one such life stage that may be sensitive to disturbance. We examined the impact of commercial scallop dredge gear on a recently settled, continental shelf fish within the context of a sand sediment, storm-dominated system, the New York Bight. From June 1999 to July 2000, experimental manipulations with spatially replicated control-impact effects were used to investigate the immediate and longer-term consequences of a dredging event on young-of-theyear (YOY) yellowtail flounder Limanda ferruginea and its benthic nursery habitat. Contrary to expectation, L. ferruginea abundance did not decrease significantly immediately after dredging. Rather, at high-density sites, continued recruitment generated increases of smaller individuals across treatments. A significant decrease of older YOY L. ferruginea and available benthic prey was observed 3 mo later following a series of major natural perturbations (Hurricanes Dennis, Floyd, and Gert). Using concomitant buoy data, we also examined the physical regime of the region as it relates to important benthic settlement windows. Increased levels of natural disturbance during the fall and winter months appeared to play a critical role in shaping inner-mid-shelf seafloor architecture, effectively obscuring any longer term dredge-related signals. The results, overall, tend to highlight the vulnerability of New York Bight shelf habitats to multiple forms of disturbance.
\end{abstract}

KEY WORDS: Dredging · Juvenile fish - Limanda ferruginea - Disturbance · New York Bight · Nursery habitat $\cdot$ Storms $\cdot$ Submersible

Resale or republication not permitted without written consent of the publisher

\section{INTRODUCTION}

In coastal marine environments, the presence of discrete microhabitats, substrates, and physical regimes exerts a profound influence on the recruitment, growth, and survival of local species (e.g. Wahle \& Steneck 1991, Tupper \& Boutilier 1995, Stoner et al. 1997). These features presumably constitute 'high quality' habitat wherein future reproductive potential is optimized (Gibson 1994, Beck et al. 2001). Further, the functional role of this quality varies with the spatial scale under consideration (Levin 1992, Mullin 1993, Langton et al. 1995). Consequently, examples of habitat selection in marine systems range from small-scale obligatory relationships (Able \& Musick 1976: inquiline snailfish Liparis inquilinus) to complex spatiotemporal exchanges (Hare \& Cowen 1996: bluefish Pomatomus saltatrix). However, life history information of this quality, at any scale, is lacking for a majority of benthic continental shelf fish species, particularly during the first year of life (USDOC 1996, Able \& Fahay 1998, Collette \& Klein-MacPhee 2002). 
The evolving concept of what makes a fish habitat 'essential' is compounded by concern over impacts by mobile bottom fishing gear, the use of which is common out to (and beyond) the shelf edge and upper slope of coastal systems worldwide (Watling \& Norse 1998). The real and potential ecological consequences of gear disturbance for a variety of continental shelf environments cannot be overstated (reviewed in Jennings \& Kaiser 1998, Auster \& Langton 1999). For example, a number of studies have convincingly documented real-time impacts of mobile gear on site-attached organisms (increased mortality, decreased biomass, recruitment failure) as well as on entire benthic communities (e.g. Eleftheriou \& Robertson 1992, Currie \& Parry 1996, Kaiser \& Spencer 1996, Freese et al. 1999). Others have reported the effects of chronic fishing (reduced complexity, diversity, niche breadth) using historical fishing records and modern side-scan techniques as guideposts (e.g. Auster et al. 1996, Collie et al. 1997, Thrush et al. 1998, McConnaughey et al. 2000). More recent work has attempted to identify the causal mechanisms behind impact-related change through analyses of sediment chemistry and nutrient composition (Watling et al. 2001). In a broad sense, intuition concerning negative impacts of fishing gear has been well supported in the scientific literature (Collie et al. 2000).

Despite a growing number of case studies, generalized effects of fishing remain unclear due to significant gaps in knowledge from multiple habitats (outer continental shelves, deeper water), disturbance regimes (chronic natural, chronic anthropogenic), and biological communities (Collie et al. 2000). Interpreting experimental results from a given habitat is difficult, as only a small subset of variables can be measured and controlled for at one time (Lindegarth et al. 2000, Hewitt et al. 2001). To complicate matters, gear effects are often embedded within a background of natural disturbance on storm-dominated shelf systems (Hall 1994). For example, Churchill (1989) argued that wave-induced oscillatory currents constitute the main mechanism for sediment resuspension over portions of the inner-mid Middle Atlantic Bight continental shelf, while trawl-generated disturbance predominates at outer shelf-slope locales. Consequently, benthic species may vary widely in their response to disturbance through the complex interaction between habitat and life history (e.g. Kaiser et al. 1998, Lindholm et al. 1999). Benthic fishes regulated by one or more critical life-stage transitions (metamorphosis, settlement) may be particularly susceptible to habitat alteration. Conversely, certain families (flatfish) may become adapted to chronically disturbed environments contingent on their functional role in the ecosystem (Hall 1999). Thus, extrapolating previous findings to novel habitats and species is a risky proposition.
The New York Bight continental shelf is an appropriate biological and physical setting for investigating the intersection of habitat quality and physical disturbance. The shelf provides habitat for over 30 species of early-stage groundfish and many of their adult counterparts (Steves et al. 2000, Steves \& Cowen 2000). Although infused with substantial stochastic variability, settlement patterns of local recruits are predictable in both a spatial and temporal sense (Sullivan et al. 2000). These shelf habitats also support active scallop and winter otter trawl fisheries that may account for elevated levels of anthropogenic disturbance out to and beyond the upper slope. Both components (nursery habitat, fishing grounds) are overlain on a seasonal, storm-driven system punctuated by rare, high magnitude events (hurricanes, winter storms; Butman 1987). The present study used a spatially replicated BACI (before-after-control-impact) experimental design (Underwood 1991, Green 1993) to investigate the effects of mobile, commercial scallop dredge gear on New York Bight young-of-the-year (YOY) yellowtail flounder Limanda ferruginea and its benthic nursery habitat. The following 4 null hypotheses concerning the spatial and temporal effects of a single dredging event were considered: specifically, that there is no significant difference from before to after dredging in $\left(H_{1}\right)$ YOY Limanda ferruginea abundance, $\left(\mathrm{H}_{2}\right)$ L. ferruginea size structure, $\left(\mathrm{H}_{3}\right)$ benthic habitat structure, and $\left(H_{4}\right)$ benthic prey abundance. In order to account for potential sources of additional shelf-wide variability, the natural physical character of the region was described using concomitant NOAA buoy data and surficial sediment records. Finally, the input and active participation of the fishing community itself (fishing vessel [FV] 'Kathy Ann', Barnegat Light, New Jersey) was sought in order to foster a more balanced view of the potential outcomes of the experiment (Churchill 1998).

\section{MATERIALS AND METHODS}

Overview and sampling design. Three sites (45, 67 and $88 \mathrm{~m}$ water depth) ${ }^{1}$ were selected near the southern limit of the New York Bight for a pre-dredge submersible survey, experimental scallop dredging, and 3

\footnotetext{
${ }^{1}$ The original study design attempted to target recruits of several different species (Limanda ferruginea, Merluccius bilinearis, Citharichthys arctifrons) over a range of depths (mid to outer shelf). However, Limanda ferruginea (Sites 1 and 2) was the only YOY groundfish with appreciable densities during all experimental time steps. Although deeper depths rarely receive $L$. ferruginea recruits, portions of the benthic data from Site 3 were analyzed for comparison purposes
} 

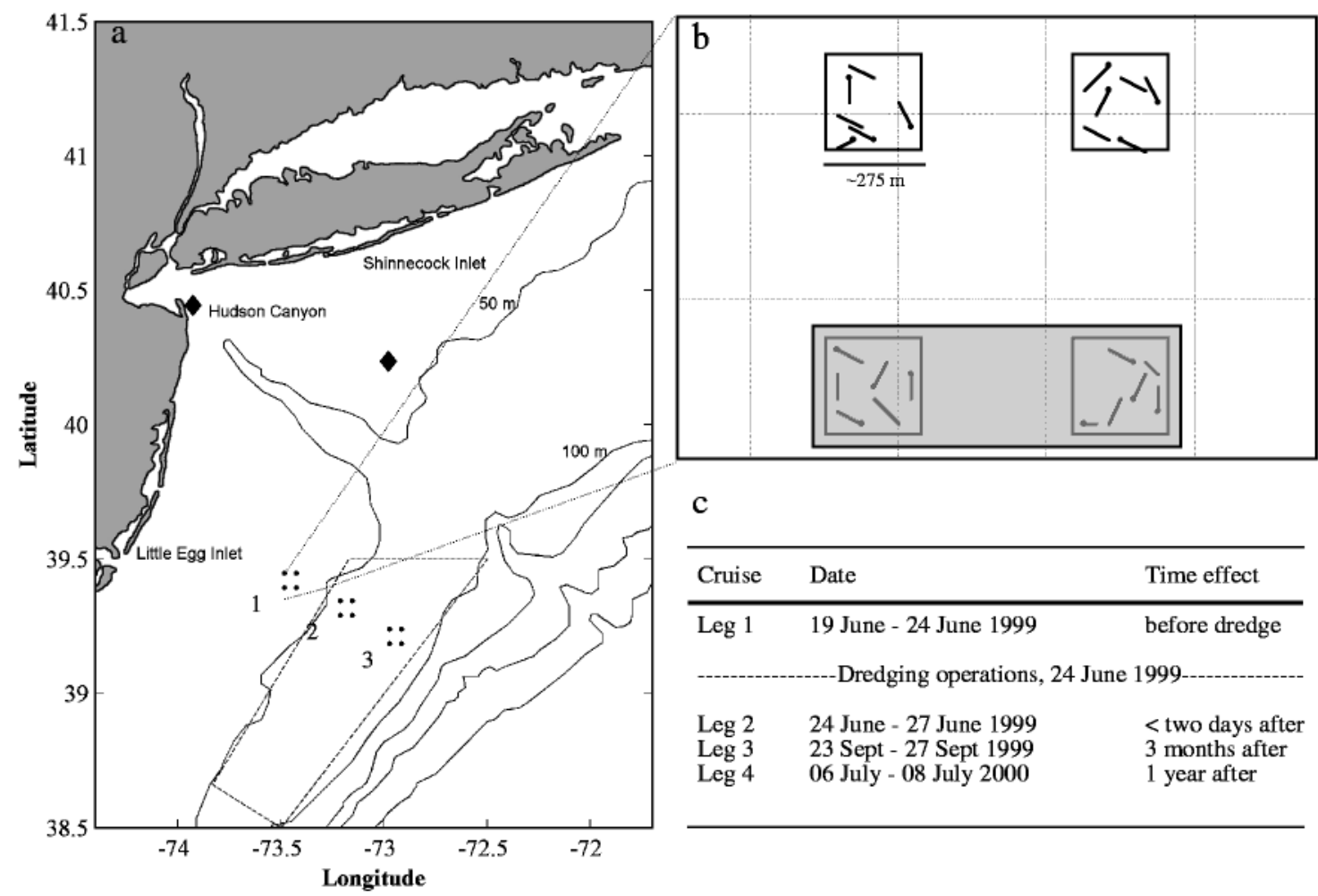

Fig. 1. (a) Locations of experimental dredging sites (::) on the New York Bight continental shelf. The trapezoidal box marks the boundary of the Hudson Canyon Closed Area. NOAA buoy locations are noted by $\bullet$. (b) Detail of seafloor sampling at an individual site (Site 1, $45 \mathrm{~m}$ water depth) depicting experimental boxes (2 control, 2 impact) with component submersible transects (line) and benthic suction samples (point) (data from July 2000 mission). The shaded rectangle denotes the dredging corridor of FV 'Kathy Ann'. (c) Sampling dates and associated time effects

post-dredge surveys $(<2 \mathrm{~d}, 3 \mathrm{mo}$, and 1 yr after impact; Fig. 1). To minimize potential confounding effects due to recent, unrelated trawling events, the 2 deep sites were located within the Hudson Canyon Closed Area (dashed box, Fig. 1a). Based on 1999 vessel monitoring system (VMS) data, it is possible that Site 1 was commercially trawled at least once in the months leading up to the experiment (NEFSC 2002). Of critical importance at each depth was the inclusion of multiple control and dredge treatments to reliably detect and interpret significant ecological effects. To this end, coordinates for four $275 \times 275 \mathrm{~m}^{2}$ experimental boxes (each separated by at least 1 box length) were selected at all sites prior to sampling (Fig. 1b). From each quartet, 2 adjacent boxes were randomly chosen for experimental dredging, with the remaining 2 designated as controls. Surveys completed in each box at each time step consisted of: (1) an underwater visual census of YOY Limanda ferruginea and associated habitat using the submersible Delta (Delta Oceanographics), (2) beam trawl collections of recruits from the support vessel Atlantic Surveyor, (3) continuous, standard meteorological data downloaded from NOAA buoy stations, (4) a series of benthic 'cores' using the submersible's suction arm.
Experimental dredging. Following the initial predredge survey and associated collections (see 'Underwater surveys' below), the commercial scallop FV 'Kathy Ann' (Barnegat Light, New Jersey) was given the coordinates to each impact box and instructed to thoroughly dredge the bottom with rigging, orientation and gear deployment following standard fishing operations. Paired New Bedford-style dredges (4.6 m wide, $89 \mathrm{~mm}$ ring size) were used for all experimental treatments. Scallop dredging was conducted as one continuous corridor between random, adjacent impact boxes to allow for a complete and realistic coverage of the bottom (Fig. 1b). To record bycatch as well as verify fishing effort and configuration, an independent scientific observer was placed on-board throughout dredging operations. Once experimental dredging was completed at each site, post-dredge surveys were initiated immediately (pending ship transit time and completion of remaining pre-dredge work).

Underwater surveys. Generally, 6 to 8 underwater visual/Hi-8 video transects ( $\sim 3$ transects per observer per dive) were completed in each box for each time step to calculate YOY fish abundance and view associated habitat change (Fig. 1b). Transects were ran- 
domly dropped from boxes where $>6$ replicates were completed (typically, during the pre-dredge survey) to maintain a balanced statistical design. Starting coordinates of individual transects were randomly chosen from the support vessel by a member of Delta Oceanographics with 2 caveats: transects needed to be within a given box and away from previously visited lines. Individual transects lasted $10 \mathrm{~min}$, during which the observer counted all YOY fishes within an $\sim 0.5 \mathrm{~m}^{2}$ total field of view and noted their location in relationship to the submersible's laser light system $(0.2 \mathrm{~m}$ apart on the bottom). A hand-held laser pointer was used to highlight cryptic individuals (partially buried flatfish) and note fine-scale habitat changes (color/rugosity/structure) for facilitated reviewing in the laboratory. After completing the third transect and collecting the final benthic 'core' (see 'Benthic sampling' below), the submersible and observer returned to the support vessel and all transects were re-inventoried for recently settled fishes from the Hi-8 tape (with the original observer and 2 additional scientists as viewers). All videos were analyzed a second and final time in the laboratory to confirm questionable ID's and/or disputed counts. Finally, distance traveled was calculated using surface-submersible fixes acquired at the start and endpoints of individual transects. Major changes in direction while underway (i.e. edge of box reached, strong current) were accompanied by a new fix and incorporated into the total distance calculation. Total area sampled was the distance traveled multiplied by the field of view width (referenced by the submersible laser lights from Hi-8 video).

Benthic fish collections. Collections of YOY Limanda ferruginea for length-frequency analysis and future otolith/growth studies were made by towing a $2 \mathrm{~m}$ beam trawl through each pair of treatment boxes following completion of submersible operations (see Steves et al. 2000, Sullivan et al. 2000 for trawl configuration). GPS bearings from the surface vessel were used to position the ship at the edge of each box before lowering the trawl to the bottom. Collections from dredge boxes were made coincident with each treatment corridor in case a box edge was reached before tow completion (see Fig. 1b). A fitted meter wheel and surface GPS positions were used as posthoc verification of bottom coverage and tow duration. The total number of tows performed at each site varied, but was contingent on obtaining a minimum of 40 to 50 ind. treatment ${ }^{-1}$ (generally 2 to 4 tows per box). All recruits collected during trawling were preserved in $95 \%$ ethanol and later measured in the laboratory to the nearest $0.01 \mathrm{~mm}$ with digital calipers (Mitutoyo). Damaged individuals as well as incidental catches of larvae were omitted from subsequent analyses.
Wave climatology and sediment transport calculations. Using NOAA buoy wave data, the frequency and magnitude of natural seabed disturbance was assessed as an additional source of variability to benthic habitats. Standard meteorological measurements (dominant wave period, $T$; significant wave height, $H$ ) were obtained from NOAA Buoy $44025\left(40.25^{\circ} \mathrm{N}\right.$, $73.17^{\circ} \mathrm{W}$ ) and NOAA C-MAN station Ambrose Light $\left(40.46^{\circ} \mathrm{N}, 73.83^{\circ} \mathrm{W}\right.$; Fig. 1a) for the period June 15 , 1999 to July 15, 2000 (available at http://seaboard. ndbc.noaa.gov/). Buoy 44025 failed for a portion of the study (November 12, 1999, to March 8, 2000), therefore, Ambrose Light data were substituted using regression techniques on a full complement of data from both stations (January 1, 1998, to January 1, 1999). Concomitant wave parameters between sites were generally well correlated $(\mathrm{r}=0.7441$ for $T, \mathrm{r}=0.8833$ for $H$ ), with the dominant wave period tending toward a poorer fit at extreme values. Conditions at Ambrose Light were used in sediment transport calculations for $10 \mathrm{~m}$ depths, all other stations $(50,100$, and $200 \mathrm{~m})$ referenced conditions at Buoy 44025. To reduce highfrequency variability, all wave data were binned into $3 \mathrm{~d}$ averages ( 130 bins for duration of experiment). Sediment types included in the analysis at each depth were: medium-coarse sand $(10 \mathrm{~m})$, medium-coarse sand $(50 \mathrm{~m})$, fine sand-silt $(100 \mathrm{~m})$, fine silt-mud $(200 \mathrm{~m})$.

Natural disturbance frequency and magnitude over the southwest portion of the New York Bight shelf under oscillatory flow (i.e. wave action) were calculated using wave climatology data. Specifically, the maximum near-bottom horizontal orbital velocity $\left(U_{\mathrm{m}}\right)$ was calculated to predict the probability of grain movement under varying wave, depth and sediment conditions. Using procedures outlined in Dyer (1986), $U_{\mathrm{m}}$ was calculated as:

$$
U_{\mathrm{m}}=H \pi / T \sinh (k h)
$$

where $h$ is the bottom depth, $T$ is the dominant wave period, and $k$ the wave number.

The near-bottom horizontal velocity was then used to calculate the maximum bottom-shear stress $\left(t_{0, \mathrm{~m}}\right)$ as detailed in Madsen \& Grant (1975):

$$
\tau_{\mathrm{o}, \mathrm{m}}=0.5 \rho f_{\mathrm{w}} U_{\mathrm{m}}{ }^{2}
$$

where $\rho$ is the density of seawater and $f_{\mathrm{w}}$ a dimensionless wave friction factor (after Jonsson 1966).

A generally accepted parameter for estimating the initiation of sediment motion under oscillatory flow is the Shields parameter, $\Psi$. The maximum bottom shear stress subsequently was used to calculate the Shields parameter for each $3 \mathrm{~d}$ period at each of 4 depths $(10$, 50, 100, and $200 \mathrm{~m}$ ):

$$
\Psi=\tau_{\mathrm{o}, \mathrm{m}} /\left(\rho_{\mathrm{s}}-\rho\right) g D
$$




\section{RESULTS}

\section{YOY Limanda ferruginea abundance $\left(H_{1}\right)$}

Over the course of the entire experiment (June 1999 to July 2000), YOY Limanda ferruginea abundance at Site 1 varied significantly with time, exhibiting a shortterm pattern consistent with a dredging effect (Fig. 2a; Table 2: overall ANOVA; Table 3: single df contrasts). Numbers of $L$. ferruginea increased significantly in all boxes $<2 \mathrm{~d}$ after dredging, but decreased significantly across all treatments 3 mo later. Approximately $1 \mathrm{yr}$ after the initial impact, abundances of new recruits (2000 yr class) were similar in magnitude to predredge levels, with no significant time effect (Fig. 2a). The interaction between temporal and spatial trends in abundance at Site 1 reflected an effect consistent with a dredging impact (significant dredge $\times$ time interaction; Table 2). The planned contrasts revealed a significant difference from before to $<2 \mathrm{~d}$ after dredging impact boxes increased with a greater overall magnitude than controls (Table 3 ). There was no significant time $\times$ box (dredge) interaction indicative of significant variability between boxes within treatments over time

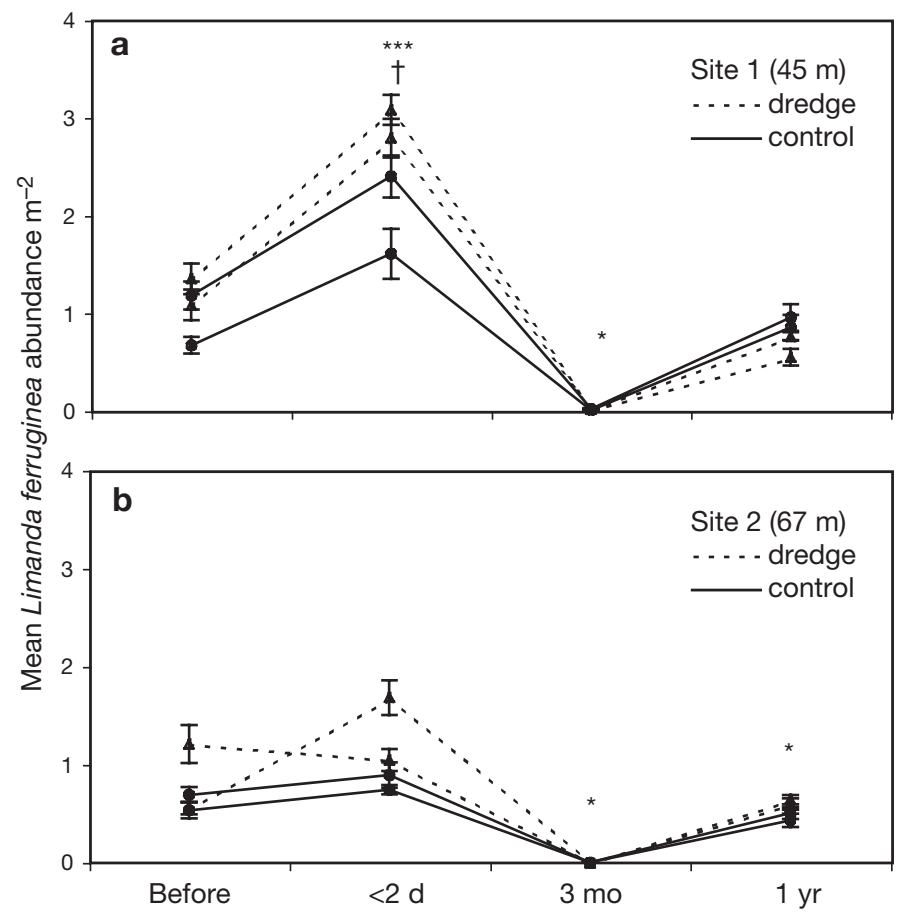

Fig. 2. Limanda ferruginea. Time series of young-of-the-year (YOY) abundance for Sites 1 (a) and 2 (b). Dashed lines indicate treatment boxes; solid lines, control. Note: $x$-axis values are not to scale to facilitate viewing of short-term effects. Error bars denote \pm 1 SE for each box. Significant deviations from initial conditions are noted $\left({ }^{*}=\right.$ time, $\dagger=$ dredge $\times$ time; ${ }^{*} \mathrm{p}<0.05 ;{ }^{* *} \mathrm{p}<0.01 ;{ }^{* * *} \mathrm{p}<0.001 ;{ }^{\dagger} \mathrm{p}<0.05 ;{ }^{+\dagger} \mathrm{p}<0.01$; $\left.{ }^{+t+} \mathrm{p}<0.001\right)$
Table 2. ANOVA table for Site 1 testing the effect of scallopdredge gear on young-of-the-year (YOY) Limanda ferruginea abundance. Effects of interest, 'time' and 'dredge $\times$ time' are indicated in bold (after Green 1993). ${ }^{*} \mathrm{p}<0.05,{ }^{* *} \mathrm{p}<0.01$, ${ }^{* * *} \mathrm{p}<0.001$. Abundance data $\log (x+1)$ transformed

\begin{tabular}{|lrrrl|}
\hline Source & df & MS & F-value & p \\
\hline Dredge & & & & \\
Box (dredge) & 1 & 0.14 & 0.77 & 0.472 \\
Time $^{\mathrm{b}}$ & 2 & 0.18 & 9.95 & $0.000^{* * *}$ \\
Dredge $\times$ time $^{\mathrm{b}}$ & 3 & 5.91 & 168.07 & $0.000^{* * *}$ \\
Time $\times$ box (dredge) & 3 & 0.20 & 5.72 & $0.034^{*}$ \\
Error & 6 & 0.04 & 1.94 & 0.082 \\
${ }^{\mathrm{a} B o x}($ dredge) as Error 1 & 80 & 0.02 & & \\
${ }^{\mathrm{b}}$ Time $\times$ box (dredge) as Error 2 & & & & \\
\hline
\end{tabular}

(Table 2). Overall, significant temporal variability from seasonal effects appears to have obscured any evidence of impact on scales greater than several months to $1 \mathrm{yr}$. On shorter time scales $(<2 \mathrm{~d})$, the effect was one of increased abundance with an embedded significant increase in dredged boxes (Fig. 2a).

Site 2 displayed lower overall temporal variability in abundance on time scales of $<2 d$ than Site 1 (with no significant dredge effect), but similar patterns over several months to 1 yr (Fig. 2b; Table 4: overall ANOVA; Table 5: single df contrasts). Limanda ferruginea abundance appeared to increase from before to $<2 \mathrm{~d}$ after dredging in the impact boxes - however, this trend was only exhibited by a single box and was lower in overall magnitude than the sustained increases of Site 1 (Fig. 2b). Further, the significant dredge effect, in the absence of a consistent dredge $\times$ time effect, indicates controls may have differed from impact boxes irrespective of time (Table 4). This pattern was superimposed on a significant time $\times$ box (dredge) interaction, signaling strong spatial variability between boxes within treatments over

Table 3. Single df contrasts of abundance for 'before' and successive 'after' time periods ('time' and 'dredge $\times$ time') at Site 1 . Final $\mathrm{p}$-values were determined by sequential Bonferroni tests at 0.05 experimentwise error rate (Sokal \& Rohlf 1997). Error $=$ time $\times$ box (dredge) ${ }^{*} \mathrm{p}<0.05,{ }^{* *} \mathrm{p}<0.01,{ }^{* * *} \mathrm{p}<0.001$

\begin{tabular}{|c|c|c|c|c|c|}
\hline Source & & df & MS & $F$-value & $\mathrm{p}$ \\
\hline \multirow[t]{3}{*}{ Time } & Time1-time2 & 1 & 3.12 & 1560.00 & $0.001^{* * *}$ \\
\hline & Time1-time3 & 1 & 5.83 & 97.08 & $0.010^{*}$ \\
\hline & Time1-time4 & 1 & 0.25 & 7.65 & 0.109 \\
\hline \multirow[t]{3}{*}{ Error } & Time1-time2 & 2 & 0.00 & & \\
\hline & Time1-time3 & 2 & 0.06 & & \\
\hline & Time1-time4 & 2 & 0.03 & & \\
\hline \multirow[t]{3}{*}{ Dredge $\times$ time } & Time1-time2 & 1 & 0.07 & 33.98 & $0.028^{*}$ \\
\hline & Time1-time3 & 1 & 0.06 & 1.01 & 0.422 \\
\hline & Time1-time4 & 1 & 0.23 & 7.05 & 0.117 \\
\hline \multirow[t]{3}{*}{ Error } & Time1-time2 & 2 & 0.00 & & \\
\hline & Time1-time3 & 2 & 0.06 & & \\
\hline & Time1-time4 & 2 & 0.03 & & \\
\hline
\end{tabular}


Table 4. ANOVA table for Site 2 testing the effect of scallopdredge gear on young-of-the-year (YOY) Limanda ferruginea abundance. Effects of interest, 'time' and 'dredge $\times$ time' are indicated in bold (after Green 1993). ${ }^{*} p<0.05,{ }^{* *} p<0.01$, ${ }^{* * *} \mathrm{p}<0.001$. Abundance data $\log (x+1)$ transformed

\begin{tabular}{|c|c|c|c|c|}
\hline Source & df & MS & $F$-value & $\mathrm{p}$ \\
\hline Dredge & 1 & 0.36 & 39.84 & $0.024^{*}$ \\
\hline Box (dredge) & 2 & 0.01 & 0.72 & 0.489 \\
\hline Time $^{b}$ & 3 & 2.22 & 22.16 & $0.001^{* *}$ \\
\hline Dredge $\times$ time $^{b}$ & 3 & 0.07 & 0.65 & 0.610 \\
\hline Time $\times$ box (dredge) & 6 & 0.10 & 7.99 & $0.000^{* * *}$ \\
\hline Error & 80 & 0.02 & & \\
\hline \multicolumn{5}{|c|}{$\begin{array}{l}{ }^{\mathrm{a}} \text { Box (dredge) as Error } 1 \\
{ }^{\mathrm{b}} \text { Time } \times \text { box (dredge) as Error } 2\end{array}$} \\
\hline
\end{tabular}

time (Table 4). Thus, at Site 2, L. ferruginea abundance exhibited a high degree of spatial variability among replicates (both time dependent and independent).

Recruits were rare or absent from the deepest location, Site 3; consequently, space and time trends were not analyzed.

\section{Limanda size structure $\left(\mathrm{H}_{2}\right)$}

Beam trawl collections taken from control and impact boxes at Site 1 paralleled submersible-derived
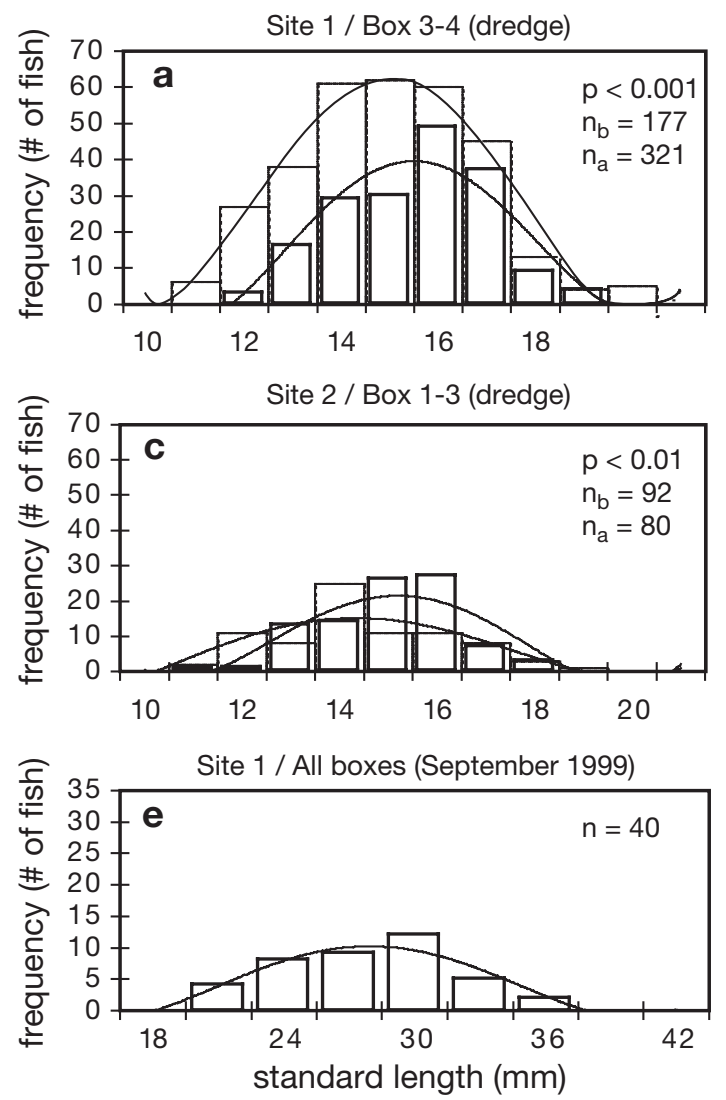

Table 5. Single df contrasts of abundance for 'before' and successive 'after' time periods ('time') at Site 2. Final p-values were determined by sequential Bonferroni tests at 0.05 experimentwise error rate (Sokal \& Rohlf 1997). Error $=$ time $\times$ box (dredge); ${ }^{*} \mathrm{p}<0.05,{ }^{* *} \mathrm{p}<0.01,{ }^{* * *} \mathrm{p}<0.001$

\begin{tabular}{|llllrc|}
\hline Source & & df & MS & F-value & p \\
\hline Time & Time1-time2 & 1 & 1.85 & 1.33 & 0.368 \\
& Time1-time3 & 1 & 3.46 & 36.85 & $0.026^{*}$ \\
& Time1-time4 & 1 & 0.23 & 19.05 & $0.049^{*}$ \\
Error & Time1-time2 & 2 & 1.39 & & \\
& Time1-time3 & 2 & 0.09 & & \\
& Time1-time4 & 2 & 0.07 & & \\
\hline
\end{tabular}

abundance estimates and, additionally, revealed a size frequency shift toward smaller individuals (Fig. 3). The temporal change in abundance observed from the submersible at Site 1 immediately after dredging was reflected in the corresponding beam trawl catch. The total number of YOY Limanda ferruginea collected increased from 177 to 321 individuals in the impact boxes and from 118 to 236 in controls (Fig. 3a,b). A relatively constant fishing effort (combined area swept) was applied from before-to-after in both treatments (954.89 and $1125.13 \mathrm{~m}^{2}$ for boxes 1 and 2, 974.84 and $1210.75 \mathrm{~m}^{2}$ for boxes 3 and 4). Embedded within this abundance increase for impact treatments was also a
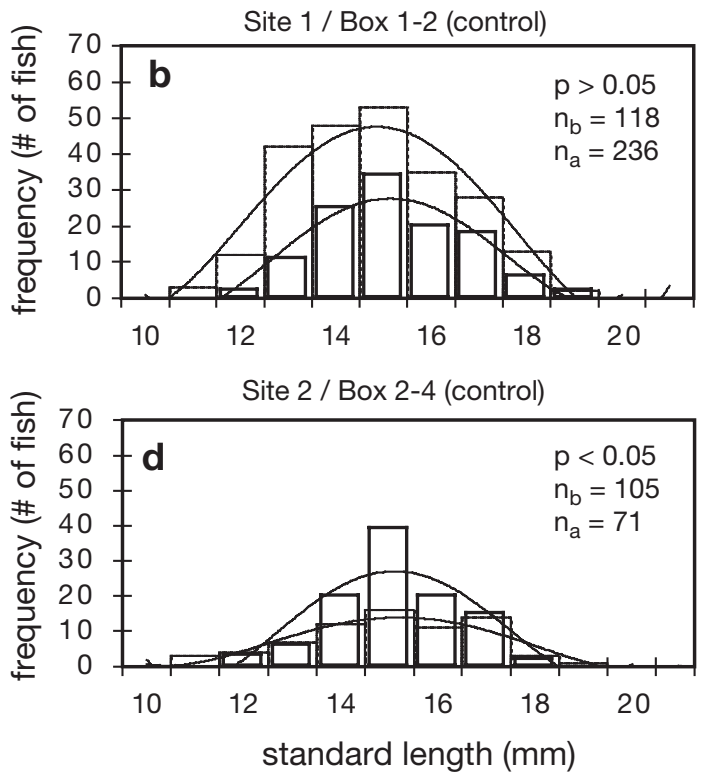

Fig. 3. Limanda ferruginea. (a-d) Length-frequency histograms for flounder in dredge and control boxes before (solid) and immediately following (dashed) experimental dredging. $p$-values indicate results of KolmogorovSmirnov 2-sample tests; $n_{\mathrm{b}}, n_{\mathrm{a}}=$ sample size before and after (sample variances heterogeneous, log-ANOVA test; Sokal \& Rohlf 1995); smoothed curves = polynomial trend lines. (e) Combined September 1999 collectionsno statistical tests performed 
significant, size-related shift toward smaller individuals $(15.05 \pm 1.54 \mathrm{~mm}$ standard length before, $14.44 \pm$ $1.83 \mathrm{~mm}$ after, $\mathrm{p}<0.001, \mathrm{~K}-\mathrm{S} 2$-sample test; Fig. 3a). Similar temporal trends in size were apparent in the control boxes, but were not significant (14.73 \pm $1.51 \mathrm{~mm}$ before, $14.35 \pm 1.67 \mathrm{~mm}$ after, $\mathrm{p}>0.05, \mathrm{~K}-\mathrm{S}$ test; Fig. 3b). September 1999 (3 mo after) catches were uncharacteristically low at Site 1 (mean standard length $26.33 \pm 4.04 \mathrm{~mm}, \mathrm{n}=40$ : all boxes; Fig. 3e), mirroring the submersible observations.

In contrast, Site 2 showed no appreciable increase in numbers from before to after dredging, but did show evidence of a shift toward smaller individuals in the impact treatment $(14.56 \pm 1.32 \mathrm{~mm}$ before, $13.98 \pm$ $1.80 \mathrm{~mm}$ after, $\mathrm{p}<0.01, \mathrm{~K}-\mathrm{S}$ test; Fig. 3c,d). Total effort was similar between treatments for Site 2; however, it is important to recall that submersible-derived abundances from individual boxes (see 'YOY Limanda ferruginea abundance') exhibited highly significant spatial and temporal variability.

Due to low abundances of YOY Limanda ferruginea, Site 3 (all time periods) and September 1999 collections at Site 2 were not analyzed. July 2000 cohorts at Sites 1 and 2 were collected for future growth-related studies, but were not analyzed with respect to changes in size frequency and structure.

\section{Benthic habitat structure $\left(\boldsymbol{H}_{3}\right)$}

Benthic habitat structure (as proxied by the frequency of natural seabed disturbance) was influenced by the interaction between depth, sediment size/density, and prevailing seasonal wave conditions. Aver-
Table 6. Multiple comparison among means of seasonal effects on wave parameters at Buoy 44025 (June 1999-July 2000). In top half of table dominant period was the dependent variable, in bottom half, significant wave height was the dependent variable. Probabilities were derived from Tukey's

HSD test. Bold values indicate no difference detected

\begin{tabular}{|lcccc|}
\hline & Spring & Summer & Fall & Winter \\
\hline Spring & - & 0.013 & $\mathbf{0 . 8 6 4}$ & 0.000 \\
Summer & 0.000 & - & 0.001 & 0.000 \\
Fall & $\mathbf{0 . 0 9 1}$ & 0.000 & - & 0.000 \\
Winter & 0.013 & 0.000 & 0.000 & - \\
\hline
\end{tabular}

age wave parameters $(H, T)$ were significantly different between all seasons, except fall and spring (multiple comparison among means, Tukey's HSD test) when hurricane activity and several early spring storms, respectively, produced similar, elevated values of both parameters (i.e. September: $1.55 \mathrm{~m}, 8.99 \mathrm{~s}$; April: $1.51 \mathrm{~m}, 7.74 \mathrm{~s}$; Table 6, Fig. 4). Using a simple transport model based on wave oscillatory currents, inner shelf habitats (10 $\mathrm{m}$ water depth) were predicted to be disturbed by wave action during all seasons, $100 \%$ of the time. This frequency fell to $16.9 \%$ for mid-shelf sites $(50 \mathrm{~m}), 3.1 \%$ at the shelf edge $(100 \mathrm{~m})$ and was nonexistent for deep, $200 \mathrm{~m}$ slope sites (0\%) (Fig. 5). Virtually all of the transport occurring at and beyond the $50 \mathrm{~m}$ isobath was storm driven (either via late summer/fall hurricanes, or winter/early spring storms). For example, during a $3 \mathrm{~d}$ period coincident with the passage of Hurricane Floyd (September 1999), significant transport was calculated to occur seaward of the $100 \mathrm{~m}$ isobath (Fig. 6b). Typical winter/spring storm scenarios generated appreciable
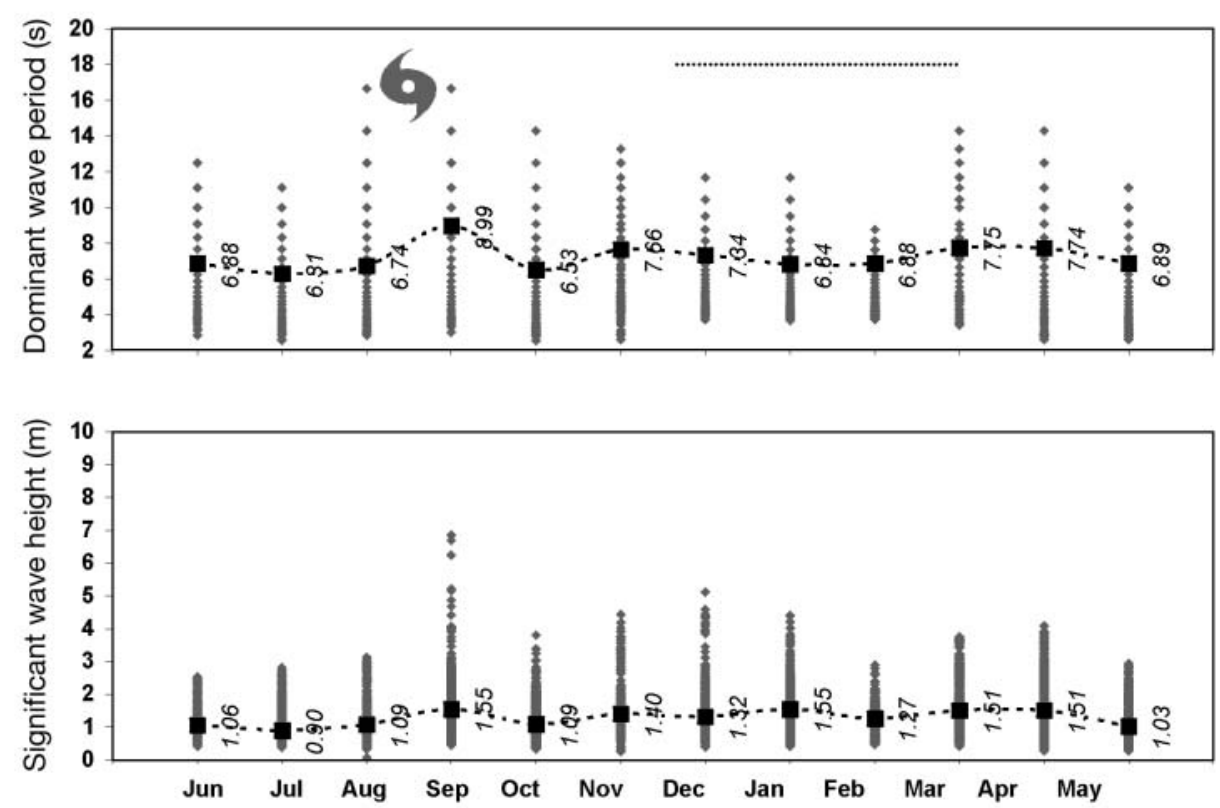

Fig. 4. Seasonal wave climatology for Buoy 44025 (south of Islip, Long Island) compiled from June 1999 to July 2000. Blocks denote mean monthly values. Individual points denote hourly values for each month. Horizontal dashed bar (top) corresponds to data derived from Ambrose Light (wave data). Hurricane symbol refers to period of intense storm activity (Hurricanes: Dennis, 24 Aug to 8 Sep; Floyd, 7 to 17 Sep; Gert, 11 to 23 Sep). Data source: NOAA National Data Buoy Center 


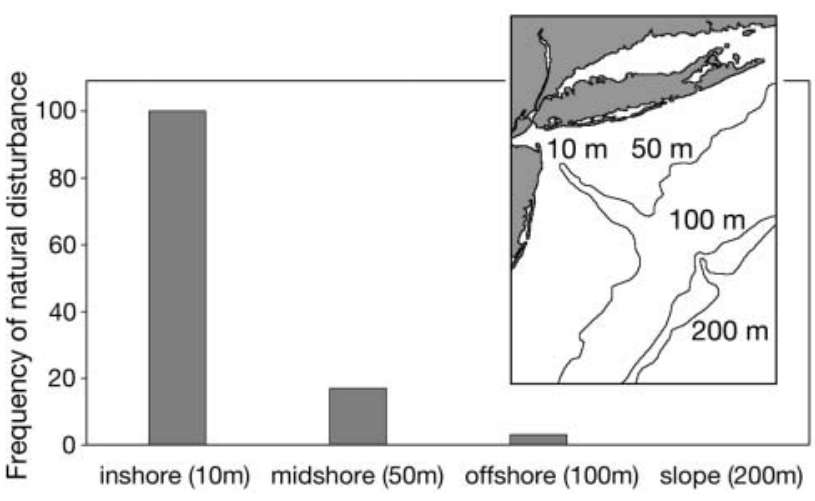

Fig. 5. Percent of time critical Shields threshold was exceeded for 4 depths (see map inset) on the New York Bight continental shelf (June 1999 to July 2000)

disturbance over 50 to $75 \%$ of the entire continental shelf (Fig. 6c). In contrast, the early summer months were the most quiescent with reduced transport occurring beyond the $50 \mathrm{~m}$ isobath (Fig. 6a) due to seasonal minima in $H$ and $T$ (July $0.90 \mathrm{~m}, 6.31 \mathrm{~s}$; Fig. 5).

In situ observations from the submersible support the extent and magnitude of the seasonal sedimenttransport predictions. In the wake of Hurricanes Dennis, Floyd and Gert (Leg 3, September 23 to 27, 1999), Sites 1 and 2 were characterized by highly irregular sand waves, occasionally reaching upwards of 50 to $60 \mathrm{~cm}$ in vertical relief (Fig. 7a). Previously extensive regions of amphipod tube mats were interspersed with characteristic excavations of bare silt/sand or filled-in shell hash. Bottom clarity at both sites was consistently turbid, indicating significant residual resuspended sediments. Although less dramatic, the deep (88 m) site displayed parallel rows of fresh, silty ripples on the order of 2 to $3 \mathrm{~cm}$ (height), reflecting the steep attenuation of wave orbital velocity with depth.

In contrast, the action of the scallop dredge (June 1999) produced a clear reduction in physical heterogeneity in treatment plots, such that the frequency of sand waves, tube mats, and biogenic depressions decreased relative to control plots (Fig. 7b,c; Sullivan et al. unpubl. data). Typical post-dredge landscapes $(<2 \mathrm{~d})$ consisted of extensive patches of clean, silty sand, interspersed with regular striations of shell hash, biogenic tubes and castings strained through the dredge teeth (Fig. 7d). Abundant mobile epifauna such as sand dollars were typically dislodged or buried under a thin layer of silt. Bottom coverage by the dredge appeared to be complete at all depths - with occasional patches of undisturbed sediment. Despite this vigorous surficial reworking, the overall impact of the dredge appeared to extend no farther than 2 to $6 \mathrm{~cm}$ below the sediment surface. Control plots remained unchanged with continuous patches of amphipod tube mats and sand dollars interspersed between
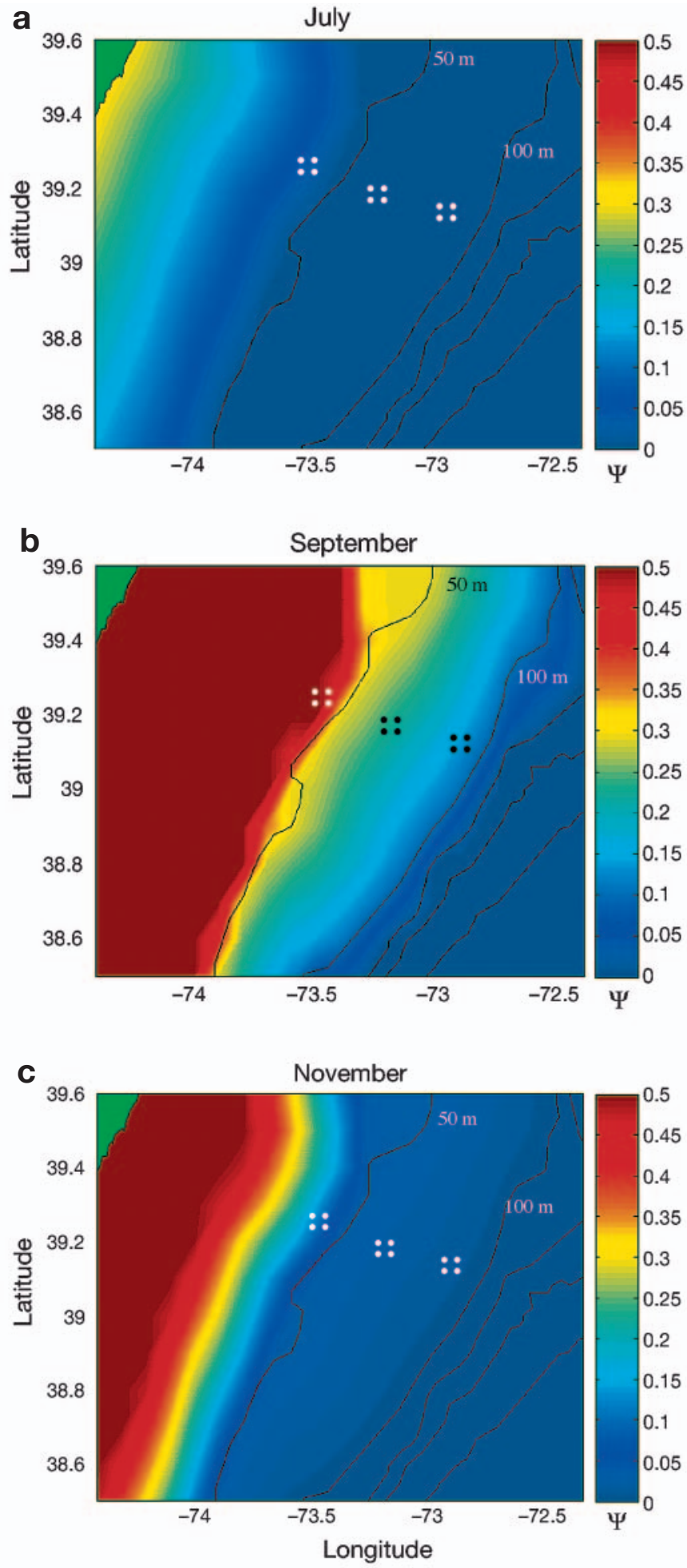

Fig. 6. Three-day average of the Shields parameter $(\psi)$, over 3 study sites, in relation to critical Shields parameter ( $\psi_{\mathrm{TH}}$ i threshold at which sediment transport is initiated, dark blue and above on color bar) for representative seasons (1999 to 2000). 'September' depicts a 3 d period coincident with the passage of Hurricane Floyd. In this example, depths greater than ca. $125 \mathrm{~m}$ do not exceed the critical value (dark blue), therefore, no transport occurs 

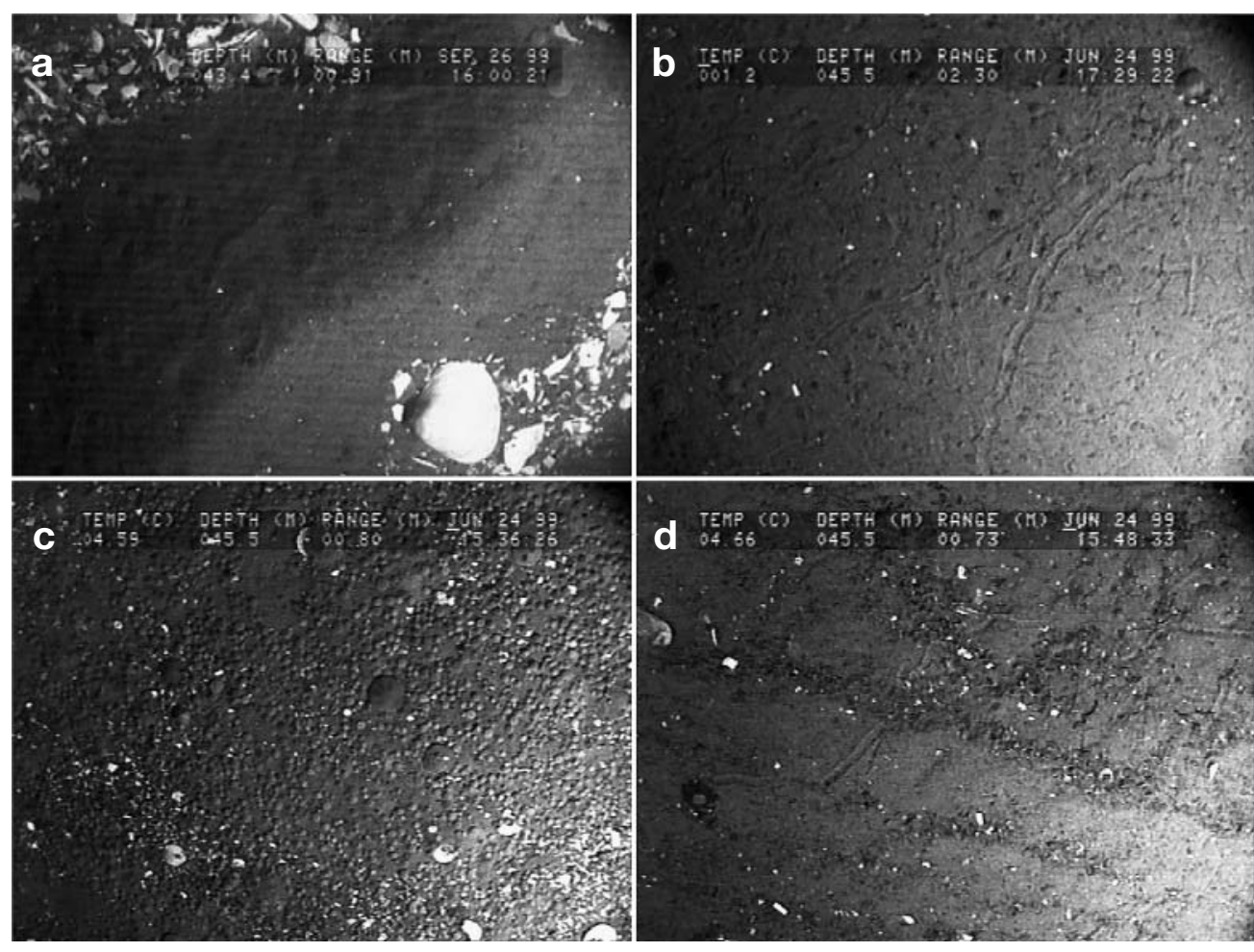

Fig. 7. (a) Storm wave crest (center) and adjacent debris-filled troughs (top left, bottom right) generated during September 1999 at Site 1. (b) Animal trails left in upper layer of recently disturbed silt from scallop dredge. (c) Dense patches of recently recruited sand dollars adjacent to a dredged box. (d) Linear striations of amphipod tubes and sand dollar recruits combed from dredge gear teeth

Table 7. ANOVA summary table for major prey items of YOY-juvenile Limanda ferruginea. Significant p-values are indicated in bold. Note: metamorphosing individuals typically consume a combination of copepods (not quantified) and small amphipods (Bowman 1981)

\begin{tabular}{|c|c|c|c|c|c|c|c|c|c|c|c|c|c|}
\hline \multirow{2}{*}{$\begin{array}{l}\text { Site } \\
\text { Source }\end{array}$} & \multirow[t]{2}{*}{ df } & \multicolumn{3}{|c|}{ — Amphipods } & \multicolumn{3}{|c|}{- Cumacea $^{\mathrm{C}}$} & \multicolumn{3}{|c|}{-Decapoda -} & \multicolumn{3}{|c|}{ Isopoda } \\
\hline & & MS & $F$-values & $\mathrm{s} p$ & MS & $F$-values & $\mathrm{s} p$ & MS & $F$-values & $\mathrm{p}$ & MS & $F$-values & $\mathrm{s}$ \\
\hline \multicolumn{14}{|l|}{$45 \mathrm{~m}$} \\
\hline Dredge $^{a}$ & 1 & 40214.38 & 0.44 & 0.577 & 714.92 & 0.13 & 0.755 & 117.13 & 0.07 & 0.816 & 40.53 & 0.10 & 0.780 \\
\hline Box(dredge) & 2 & 92042.19 & 1.88 & 0.163 & 5584.82 & 4.82 & 0.012 & 1679.91 & 7.70 & 0.001 & 399.61 & 5.46 & 0.007 \\
\hline Time $^{b}$ & 3 & 102033.81 & 7.51 & 0.019 & 18572.31 & 12.48 & 0.005 & 1800.95 & 6.33 & 0.027 & 455.00 & 7.55 & 0.018 \\
\hline Dredge $\times$ time $^{b}$ & 3 & 25361.50 & 1.87 & 0.236 & 223.18 & 0.15 & 0.926 & 657.51 & 2.31 & 0.176 & 39.45 & 0.66 & 0.609 \\
\hline Time $\times$ box(dredge $)$ & 6 & 13593.12 & 0.28 & 0.945 & 1488.76 & 1.28 & 0.283 & 284.65 & 1.31 & 0.273 & 60.25 & 0.82 & 0.558 \\
\hline Error & 48 & 48924.76 & & & 1159.93 & & & 218.18 & & & 73.22 & & \\
\hline \multicolumn{14}{|l|}{$67 \mathrm{~m}$} \\
\hline Dredge $^{a}$ & 1 & 495758.88 & 0.44 & 0.575 & 0.09 & 1.59 & 0.334 & & & & & & \\
\hline Box(dredge) & 2 & 1127558.06 & 6.19 & 0.004 & 0.06 & 0.11 & 0.897 & & & & & & \\
\hline Time $^{\mathrm{b}}$ & 3 & 647715.26 & 1.43 & 0.325 & 1.12 & 3.15 & 0.108 & & & & & & \\
\hline Dredge $\times$ time $^{\mathrm{b}}$ & 3 & 911772.31 & 2.01 & 0.214 & 0.17 & 0.48 & 0.711 & & & & & & \\
\hline Time $\times$ box $($ dredge $)$ & 6 & 453914.31 & 2.49 & 0.035 & 0.36 & 0.67 & 0.671 & & & & & & \\
\hline Error & 48 & 182037.96 & & & 0.53 & & & & & & & & \\
\hline \multicolumn{14}{|l|}{$88 \mathrm{~m}$} \\
\hline Dredge $^{\mathrm{a}}$ & 1 & 198625.79 & 4.49 & 0.168 & & & & & & & & & \\
\hline Box(dredge) & 2 & 44256.01 & 0.63 & 0.539 & & & & & & & & & \\
\hline Time $^{\mathrm{b}}$ & 3 & 65511.90 & 1.27 & 0.366 & & & & & & & & & \\
\hline Dredge $\times$ time $^{\mathrm{b}}$ & 3 & 105695.34 & 2.05 & 0.209 & & & & & & & & & \\
\hline Time $\times$ box(dredge $)$ & 6 & 51574.07 & 0.74 & 0.625 & & & & & & & & & \\
\hline Error & 34 & 70206.89 & & & & & & & & & & & \\
\hline
\end{tabular}


regular fields of sand waves. No evidence of a dredging impact of any kind was apparent in September 1999 or July 2000.

\section{Benthic prey abundance $\left(H_{4}\right)$}

Prey items of YOY Limanda ferruginea retrieved from the suction samples failed to exhibit a positive or negative change consistent with a dredging impactbut did reflect significant seasonal variability (contingent on depth) (Fig. 8, Table 7). Benthic cores at all 3 sites were dominated by amphipods (Table 8). Taxa with low abundances at a given site (Site 2: decapods, isopods; Site 3: cumaceans, decapods, isopods) were omitted from the analysis. At Site 1, patterns of prey abundance (amphipods, cumaceans, decapods, isopods) were characterized by significant variation over time with synchronous declines in late September (Fig. 8). This trend parallels submersible and beam-trawl derived estimates for $L$. ferruginea. Although no impact-related effect was uncovered, it is important to note the high degree of variability between sampling locations independent of time (significant box [dredge] interaction for cumaceans, decapods, isopods; Table 7). The seasonal pattern was similar at Site 2 for amphipods; however, time-related trends were accompanied by appreciable between-box variability (time $x$ box [dredge]; Fig. 8, Table 7). Conversely, seasonal patterns for cumaceans at Site 2 and amphipods at Site 3 were less pronounced with relatively stable abundances over time (Fig. 8, Table 7). In summary, major variations in the prey base of YOY juveniles occur seasonally (time) with additional variability generated between sampling locations (box [dredge] and time $\times$ box [dredge]). Seasonal effects were most pronounced at the shallow Site 1 and decreased in significance with depth. No functional relationship was apparent between prey abundance and dredging with time. A power analysis of the before-after time step at Site 1 revealed the overall power to detect a dredgerelated impact as moderate-low (reduction in mean abundance of 30 and $50 \%$, respectively: amphipods 35 and $51 \%$; cumaceans 24 and $39 \%$; isopods 18 and $34 \%$; decapods 36 and $47 \%$ ). This result is largely a reflection of the limited carrying capacity of the submersible (maximum 2 cores per dive) as well as the inherent natural patchiness of individual taxa.

\section{DISCUSSION}

This field investigation into

Fig. 8. Time series of mean abundance $( \pm 1 \mathrm{SE})$ of major prey items of young-ofthe-year (YOY) juvenile Limanda ferruginea for Sites $1(45 \mathrm{~m}), 2(67 \mathrm{~m})$, and $3(88 \mathrm{~m})$. Dashed lines indicate dredge boxes; solid lines, control. Note varying scale of $y$-axis the effects of mobile fishing gear on Limanda ferruginea recruit abundance and essential fish habitat structure revealed 3 primary results: (1) an initial post-dredge increase 
Table 8. Rank order of major amphipod genera by site from benthic core samples. Classification follows Dickinson et al. (1980)

\begin{tabular}{|lrc|}
\hline Amphipod genera & Number & \% of total \\
\hline Site 1 & & \\
Unicola & 2465 & 62.77 \\
Erichthonius & 470 & 11.97 \\
Phoxocephalus & 312 & 7.94 \\
Ampelisca/Byblis & 184 & 4.69 \\
Paraphoxus & 174 & 4.43 \\
Monoculodes & 145 & 3.69 \\
Protohaustorius & 47 & 1.20 \\
Site 2 & & \\
Ampelisca/Byblis & 4835 & 56.55 \\
Unicola & 2681 & 31.36 \\
Erichthonius & 332 & 3.88 \\
Photis & 244 & 2.85 \\
Phoxocephalus & 146 & 1.71 \\
Site 3 & & \\
Ampelisca/Byblis & 3259 & 88.66 \\
Unicola & 276 & 7.51 \\
Photis & 90 & 2.41 \\
\hline
\end{tabular}

of recently-settled L. ferruginea immediately following gear disturbance, (2) strong seasonal trends in both YOY $L$. ferruginea and benthic invertebrate abundance, and (3) significant habitat reworking by wave action out to, and beyond, the mid-continental shelf. These 3 findings suggest that the New York Bight shelf is a physically dominated system subjected to extensive seasonal reworking by natural processes. In this context, a single dredging event has only a minimal impact on recently settled recruits and associated habitat. Taken individually (below), each point suggests that the settlement dynamics of local benthic species may be shaped, in part, by individual morphology and behavior, preferred nursery habitat and depth, as well as the magnitude and timing of natural processes.

\section{Dredging response on time scales of less than $2 \mathrm{~d}$}

Conservatively, the complex interaction between settlement magnitude, substrate availability, and recruit activity levels appears to be driving short-term patterns in recently settled Limanda ferruginea abundance. Scientific impartiality aside, it was difficult to envision a $400 \mathrm{~kg}$ mobile scallop dredge having any impact other than a negative one on a sedentary, early stage benthic fish. For example, Collie et al. (2000) recently used a meta-analytical approach to examine trends in impact and recovery rates binned by gear, location, habitat, and biological class. Not a single scenario offered a 'positive' short-term response to dredging (i.e. change in abundance over 1 d) although longer-term trends tended to vary with physical setting. Because of the present study's atypical result (significant, positive dredge effect over $<2 \mathrm{~d}$ at Site 1), it is worth evaluating the possible mechanistic reasons for this response.

First, due to the sheer magnitude of the settlement event itself, additional individuals may have successfully recruited between the final pre- and initial postdredge survey. This would explain the simultaneous increase of recruits (with time) in both Site 1 treatments. The occurrence of smaller-sized individuals based on length-frequency data tends to support this notion with increased abundances in all boxes (accompanied by an embedded, significant size-related shift in dredged boxes). Accordingly, the significant, higher magnitude increase exhibited by the dredge treatments could be the byproduct of newly available settlement habitat (i.e. flat, homogenized sand), thus, creating a 'match' between recruitment and percent cover of a preferred substrate (Cushing 1975, Auster \& Langton 1999).

Second, observed distributions could be the result of technical artifacts rather than any realistic recruitment-oriented premise (Benedetti-Cecchi et al. 1996, Thompson \& Mapstone 1997, Kulbicki 1998). Scientific observers may have become more competent with time at observing small, cryptic organisms (i.e. improved search technique and image), in essence, 'under sampling' the pre-dredge portion of the experiment. Increased recruit activity levels (after disturbance) could render the same, exaggerated effect in dredged treatments. However, after initial viewing and reviewing of video transects (with multiple, independent observers), the former scenario appears unlikely. Further, beam trawl catches tended to mirror prevailing submersible-derived observations. Nevertheless, it was difficult to quantitatively discount the possibility of a stress-induced response leading to increased recruit detection.

A final scenario involves opportunistic feeding and/or emigration from non-experimental habitats. Numerous studies have suggested that disturbance events attract scavengers and other mobile predators due to sudden, highly available pulses of organic matter and benthic prey (Caddy 1973, Murawski \& Serchuk 1989, Ramsay et al. 1998). Overall response magnitude, however, tends to reflect the scaled, physiological limitations of individual species (Kaiser \& Spencer 1994). In this study, boxes were designed to minimize edge effects from outlying Limanda ferruginea recruits. Given the scaling relationship between box length $(\sim 275 \mathrm{~m})$ and average recruit length ( 10 to $15 \mathrm{~mm})$, the chance of an edge-related result integrating over an entire box area is unlikely. 
Site 2 displayed a similar temporal pattern to that of Site 1 (increased abundance following dredging); however, the effect was only observed in a single dredged box. This significant between-box variability rendered the main effect of interest negligible. Rather than traditional sample size considerations, this phenomenon is probably attributable to asynchronous spatial and seasonal ecological variance (see recent work by Drabsch et al. 2001, Schratzberger et al. 2002 for macro and meiofaunal communities).

Overall, the large abundance of settling recruits may have masked any functional dredge-induced response at any of the experimental sites. This saturation of nursery habitats has been observed previously for Limanda ferruginea in the New York Bight (Steves et al. 2000, Sullivan et al. 2000) and may function as a bet-hedging strategy against an array of patchy microhabitats (MacCall 1990). In the present study, the fate of these recruits in the weeks immediately following the dredging event is unknown.

\section{Seasonal response}

Abundances of YOY Limanda ferruginea and associated benthic prey items (amphipods, cumaceans, decapods, isopods) were dramatically reduced in September 1999, resulting in a highly significant seasonal effect. For the benthic infauna, this pattern was distinct in the mid-shelf region and more ambiguous at offshore sites. Although statistical power was moderate, the seasonal component clearly overshadowed any appreciable dredge-induced response (either negative or positive). These findings are similar in scope to recent experimental work by Schratzberger et al. (2002), which concluded that seasonal variability dominated patterns of meiofaunal abundance on fishing grounds in the southern North Sea. In the present study, observations were collected approximately $1 \mathrm{wk}$ after a series of intense, late summer disturbances (Hurricanes Dennis, Floyd, and Gert). Based on previous work in the New York Bight region, there are several explanations for the abundance patterns observed in the wake of these storms.

First, the synchronous declines between older YOY flounder and benthic prey may have been the byproduct of increased physical stress. On the continental shelf proper, it is assumed that local populations are adapted to deal with some minimal threshold of wave stress (Hall 1994), with large-scale community change driven by acute, episodic events (i.e. Ebeling et al. 1985: kelp forests; Underwood 1999: rocky intertidal). As benthic habitats in this study were reworked extensively out to the $100 \mathrm{~m}$ isobath and beyond, individuals occupying heavily disturbed mid-shelf sites were likely exposed to prolonged, high-energy conditions. Direct physical measurements taken from the coastal mixing and optics experiment during the passage of Hurricanes Edouard and Hortense (fall 1996, Southern New England shelf, $70 \mathrm{~m}$ water depth) provide a detailed glimpse into the environmental changes associated with a disturbance of this magnitude (Dickey \& Williams 2001). During the passage of both storms, in situ ADCP (Acoustic Doppler Current Profiler) mooring data revealed current velocities in the upper $35 \mathrm{~m}$ approaching $>65 \mathrm{~cm} \mathrm{~s}^{-1}$ (Chang et al. 2001). On the seafloor, tripod measurements recorded 10-fold increases in average wave orbital velocities, while integrated optical instrumentation documented benthic sediments and detritus re-suspended $<30 \mathrm{~m}$ from the ocean surface (Gardner et al. 2001, Chang et al. 2001). Perhaps most impressively, significant sediment transport was first observed as the system traveled approximately $900 \mathrm{~km}$ south of the study site. In this respect, even relatively distant storms have the potential to invoke a major stress on the benthic constituents of a marine ecosystem.

A second, related seasonal phenomenon acting on YOY Limanda ferruginea in the New York Bight is the mid-shelf cold pool, a body of isolated winter water typically located between the 40 and $70 \mathrm{~m}$ isobaths (Steves et al. 2000). Recently settled L. ferruginea exhibit a high degree of inter-annual fidelity to the cross-shelf breadth and extent of this cold cell, with settlement magnitude dependent on absolute bottom temperature (Sullivan et al. 2000). Typically, the cold pool gradually warms over the course of the summer until fall bottom and surface temperatures approach equilibrium (Houghton et al. 1982). However, wave action from large-scale tropical storms and hurricanes may contribute to an early de-stratification (Chang \& Dickey 2001). During the 1996 settlement season, a turnover event initiated by Hurricanes Edouard and Hortense was linked with magnitude-order declines in YOY L. ferruginea abundance on the New York Bight shelf (Steves et al. 2000).

Unfortunately, the direct impacts of storms on benthic organisms (either from physical or temperature related stress) are difficult to document and probably vary widely with trophic level. Increased turbidity and turbulence have been implicated as factors in decreased prey detection and foraging success (Weissburg \& Zimmer-Faust 1993, Benfield \& Minello 1996, Gregory \& Levings 1998), as well as depressed levels of benthic production (Emerson 1989, Nelson et al. 1999). However, wave disturbance is not necessarily negative and may depend on an organism's functional role as predator or prey. Pile et al. (1996) observed an increase in juvenile blue crab Callinectes sapidus survival during and after a major tropical storm in Chesa- 
peake Bay, and related this trend to decreased foraging success by predators (moderated by a sudden temperature drop and/or increased turbidity). In the present study, it is unclear whether short-term episodic stress or longer-term demographic trends are responsible for the seasonal minima in abundance. Arrival to benthic nursery habitats often coincides with a complex array of density-dependent processes that significantly modify abundances throughout the first year of life (Sissenwine 1984, Gibson 1994). In this respect, attributing cause and effect to 'before-after' snapshots may foster a misleading interpretation of the actual dynamics of the system (Underwood 1991, 2000). However, dramatic storm activity observed in September 1999 appeared to have no significant effect on the following year's new recruits, as well as the overall distribution of benthic habitat types.

\section{Frequency and magnitude of seabed disturbance}

The frequency of occurrence and relative magnitude of anomalous events can potentially offer valuable insight into the dynamics of a particular ecosystem (even while confounding experimental treatment effects) (Hurlbert 1984, Dayton et al. 1992, Turner et al. 1993). In this study, the disturbance events (Hurricanes Dennis, Floyd, and Gert) were of such a remarkable intensity and spatial coverage that it shifted our perception of how shelf communities are structured on seasonal time scales. Further, the subsequent recovery of the system provided an equally powerful contrast between the resilience of inner-mid continental shelf habitats and the potential precariousness of low disturbance, outer shelf locales.

The natural disturbance regime of a continental shelf ecosystem can partially be estimated by examining the sequential distribution of bottom types with depth. Sediment sequences in the New York Bight apex, for example, represent the endpoint of thousands of years of local atmospheric forcing, with the 10 to $20 \mathrm{~m}$ isobath marking typical wave base conditions $(\sim \Lambda / 2$, where $\Lambda$ is wavelength) (Vincent et al. 1981). Unfortunately, the notion of 'wave base' approximates an average set of conditions and does not provide insight into the frequency, magnitude and seasonality of anomalous events. For example, Komar et al. (1972) found symmetrical ripple marks at depths of over $200 \mathrm{~m}$ off of the Oregon coast corresponding with characteristics of long period storm waves (15 s period). Using a sequence of bottom photographs, Butman \& Moody (1983) similarly documented the shelf-wide effects (Georges Bank to Delaware Bay) of a winter Northeaster on Middle Atlantic Bight sediment transport and gross bottom morphology. On Georges Bank, winter storms occur on average every $10 \mathrm{~d}$ (December to March), marked by less-frequent periods of intense activity that rework habitats well seaward of the median wave base.

Sediment transport calculations in this study estimated transport initiation over and beyond the $100 \mathrm{~m}$ isobath, with frequent disturbance occurring out to the mid-continental shelf (50 $\mathrm{m}$ isobath). The former scenario was verified by submersible observations of surface wave ripples at depths $>80 \mathrm{~m}$ approximately $4 \mathrm{~d}$ after the passage of Hurricane Gert. By way of contrast, the mid-shelf sites ( 45 and $67 \mathrm{~m}$ ) were considerably reworked with highly irregular ridge $(0.5 \mathrm{~m}$ in height) and trough topography characterized by disorganized tube mats and a scarcity of mobile megafauna. This contrast between mid- and outer-shelf disturbance regimes reflects the exponential attenuation of wave orbital velocities with depth. Perhaps even more striking than the sheer magnitude of the bedforms themselves was their complete reworking over the course of the following $6 \mathrm{mo}$, such that July 2000 conditions mirrored average summer seafloor topography (low relief sand waves). Thus, the frequency of winter storms has an appreciable effect on longer-term patterns of seafloor architecture. In general, these results are similar to more detailed calculations by Vincent et al. (1981) and represent the logical extension of work by DeAlteris et al. (1999) for estuaries and inner continental shelf environments.

It is important to note that this experiment did not specifically address the effects of chronic, mobile gear disturbance on seafloor habitats (see Kaiser et al. 2000, McConnaughey et al. 2000). Rather, a single, intense dredging event was embedded within the larger context of seasonal, wave-generated disturbance. Vessel monitoring as well as NMFS sea sampling data clearly identify the New York Bight shelf as a major center of frequent, repeated trawling activity (Auster \& Langton 1999, NEFSC 2002). Chronic trawling has the potential to modify, remove and replace substrates critical for growth and survival (Watling \& Norse 1998), as well as shift the overall composition of benthic communities (Collie et al. 1997). Although logistically difficult, in order to truly scale the relationship between dredging and natural processes, future comparisons must be made on the scale of the actual fishery, rather than a single event (Collie at al. 2000). Nevertheless, the findings of this study suggest that the effects of bottom trawling may be less critical in storm-dominated, sandsediment environments.

\section{SUMMARY}

In conclusion, the goal of this study was to quantify the short $(<2 \mathrm{~d})$ and longer-term ( 3 mo to $1 \mathrm{yr})$ effects of 


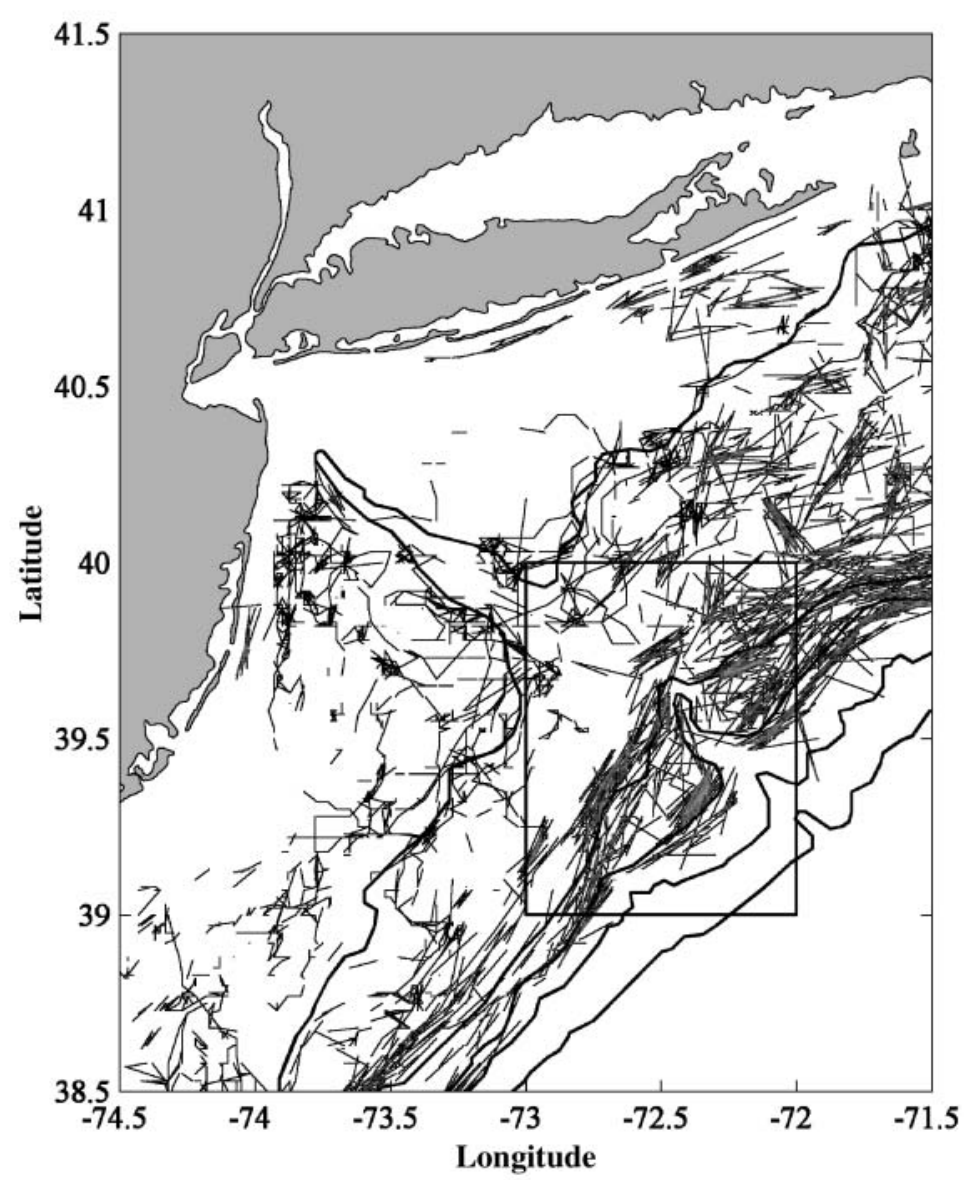

Fig. 9. Aggregations of mobile fishing gear sets (black lines: scallop dredges; grey lines: otter trawls) for the New York Bight continental shelf and shallow slope, 1989 to 1994. Data were compiled and plotted from the National Marine Fisheries Service sea sampling database. The rectangle corresponds to Statistical Area 616-a sub-region of particularly intense trawling activity

a dredging event on essential fish habitat using a common, recently settled flatfish Limanda ferruginea as the target species. YOY $L$. ferruginea settling onto New York Bight continental shelf nursery grounds exhibited short-term increases in abundance from anthropogenic disturbance, presumably through the alteration of available settlement habitat $\left(H_{1}, H_{2}\right)$. However, these distributional and structural changes were relatively short-lived given the sequence of frequent, intense natural disturbance events during the fall and winter months (detectable through standard wave measurements and corresponding changes in seafloor architecture; $H_{3}$ ). Accordingly, flounder recruits and components of their benthic prey-base exhibited strong seasonal variability of a greater overall scale and magnitude than that created by mobile scallop dredging alone $\left(H_{1}, H_{4}\right)$. Taken as a whole, these findings highlight the relative vulnerability of various shelf habitats to multiple forms of seafloor dis- turbance. If one considers the dominant distribution and abundance of trawl operations in the New York Bight (Fig. 9), future studies should address the relative susceptibility of low energy, high relief outer shelf habitats to mobile fishing gear impacts.

Acknowledgements. The participation of the captains and crew of FV 'Kathy Ann' and RV 'Atlantic Surveyor', along with Delta Oceanographics made for a truly collaborative research endeavor. We thank G. W. Bell, E. Martino (Leg I), P. Clarke, D. M. Nemerson (Leg II) and T. M. Grothues (Leg III) for their help in the field. R. J. Diaz (VIMS) offered valuable suggestions on the processing of benthic samples. Discussions with J. P. Walsh (SCRIPPS) and J. Van De Kreeke (RSMAS) substantially improved the sediment transport analysis and interpretation, while J. P. Walsh provided several programs for analyzing transport under ocean waves. J. Palmer (Woods Hole) accessed the historical trawling data from the NMFS sea sampling database. Comments on earlier versions of this manuscript were provided by S. Sponaugle, D. Die, G. L. Hitchcock, C. B. Paris, J. P. Walsh, and 3 anonymous reviewers. Finally, we gratefully acknowledge the continued support of the National Underwater Research Program (MAB-99-07). This is a Rosenstiel School of Marine and Atmospheric Science Center for Sustainable Fisheries Contribution and Rutgers University Institute of Marine and Coastal Sciences Contribution No. 2003-23.

\section{LITERATURE CITED}

Able KW, Fahay MP (1998) The first year in the life of estuarine fishes in the Middle Atlantic Bight. Rutgers University Press, New Brunswick, NJ

Able KW, Musick JA (1976) Life history, ecology, and behavior of Liparis inquilinus (Pisces: Cyclopteridae) associated with the sea scallop, Placopecten magellanicus. Fish Bull 74:409-421

Auster PJ, Langton RW (1999) The effects of fishing on fish habitat. Am Fish Soc Symp 22:150-187

Auster PJ, Malatesta RJ, Langton RW, Watling L and 5 others (1996) The impacts of mobile fishing gear on seafloor habitats in the Gulf of Maine (Northwest Atlantic): implications for conservation of fish populations. Rev Fish Sci 4: 185-202

Beck MW, Heck KL Jr, Able KW, Childers DL and 9 others (2001) The identification, conservation, and management of estuarine and marine nurseries for fish and invertebrates. Bioscience 51:633-641

Benedetti-Cecchi L, Airoldi L, Abbiati M, Cinelli F (1996) Estimating the abundance of benthic invertebrates: a comparison of procedures and variability between observers. Mar Ecol Prog Ser 138:93-101

Benfield MC, Minello TJ (1996) Relative effects of turbidity and light intensity on reactive distance and feeding of an estuarine fish. Environ Biol Fish 46:211-216

Bowman RE (1981) Food of 10 species of northwest Atlantic juvenile groundfish. Fish Bull 79:200-206

Butman B (1987) The effect of winter storms on the bottom. In: Backus RH (ed) Georges Bank. MIT Press, Cambridge, MA, p 74-78

Butman B, Moody JA (1983) Observations of bottom currents and sediment movement along the US east coast continental shelf during winter. In: McGregor BA (ed) Environmental geologic studies on the United States Mid and 
North Atlantic outer continental shelf area, 1980-1982, Vol III. Final report to US Bureau of Land Management, New York

Caddy JF (1973) Underwater observations on tracks of dredges and trawls and some effects of dredging on a scallop ground. J Fish Res Board Can 30:173-180

Chang GC, Dickey TD (2001) Optical and physical variability on timescales from minutes to the seasonal cycle on the New England shelf: July 1996 to June 1997. J Geophys Res (C Oceans) 106:9435-9453

Chang GC, Dickey TD, Williams AJ (2001) Sediment resuspension over a continental shelf during Hurricanes Edouard and Hortense. J Geophys Res (C Oceans) 106: 9517-9531

Churchill JH (1989) The effect of commercial trawling on sediment resuspension and transport over the Middle Atlantic Bight continental shelf. Cont Shelf Res 9:841-864

Churchill JH (1998) Sediment resuspension by bottom fishing gear. In: Dorsey EM, Pederson J (eds) Effects of fishing gear on the sea floor of New England. Conservation Law Foundation, Boston, p 134-137

Collette BB, Klein-MacPhee G (2002) Bigelow and Schroeder's Fishes of the Gulf of Maine, 3rd edn. Smithsonian Institution Press, Washington, DC

Collie JS, Escanero GA, Valentine PC (1997) Effects of bottom fishing on the benthic megafauna of Georges Bank. Mar Ecol Prog Ser 155:159-172

Collie JS, Hall SJ, Kaiser MJ, Poiner IR (2000) A quantitative analysis of fishing impacts on shelf-sea benthos. J Anim Ecol 69:785-798

Currie DR, Parry GD (1996) Effects of scallop dredging on a soft sediment community: a large-scale experimental study. Mar Ecol Prog Ser 134:131-150

Cushing DH (1975) Marine ecology and fisheries. Cambridge University Press, Cambridge

Dayton PK, Tegner MJ, Parnell PE, Edwards PB (1992) Temporal and spatial patterns of disturbance and recovery in a kelp forest community. Ecol Monogr 62:421-445

DeAlteris J, Skrobe L, Lipsky C (1999) The significance of seabed disturbance by mobile fishing gear relative to natural processes: a case study in Narragansett Bay, Rhode Island. Am Fish Soc Symp 22:150-187

Dickey TD, Williams AJ (2001) Interdisciplinary ocean process studies on the New England Shelf. J Geophys Res (C Oceans) 106:9427-9434

Dickinson JJ, Wigley RL, Brodeur RD, Brown-Leger S (1980) Distribution of gammaridean amphipoda (crustacea) in the Middle Atlantic Bight region. NOAA Tech Rep NMFS SSRF-741:1-46

Drabsch SL, Tanner JE, Connell SD (2001) Limited infaunal response to experimental trawling in previously untrawled areas. ICES J Mar Sci 58:1261-1271

Dyer KR (1986) Coastal and estuarine sediment dynamics. John Wiley \& Sons, New York

Ebeling AW, Laur DR, Rowley RJ (1985) Severe storm disturbances and reversal of community structure in a southern California kelp forest. Mar Biol 84:287-294

Eleftheriou A, Robertson MR (1992) The effects of experimental scallop dredging on the fauna and physical environment of a shallow sandy community. Neth J Sea Res 30: 289-299

Emerson CW (1989) Wind stress limitation of benthic secondary production in shallow, soft-sediment communities. Mar Ecol Prog Ser 53:65-77

Freese L, Auster PJ, Heifetz J, Wing B (1999) Effects of trawling on seafloor habitat and associated invertebrate taxa in the Gulf of Alaska. Mar Ecol Prog Ser 182:119-126
Gardner WD, Blakey JC, Walsh ID, Richardson MJ and 7 others (2001) Optics, particles, stratification, and storms on the New England continental shelf. J Geophys Res (C Oceans) 106:9473-9497

Gibson RN (1994) Impact of habitat quality and quantity on the recruitment of juvenile flatfish. Neth J Sea Res 32: 191-206

Grant WD, Madsen OS (1979) The threshold of grain motion under oscillatory flow in a laboratory wave channel. J Sediment Petrol 49:287-294

Green RH (1993) Application of repeated measures designs to environmental impact and monitoring studies. Aust J Ecol 18:81-98

Gregory RS, Levings CD (1998) Turbidity reduces predation on migrating juvenile Pacific salmon. Trans Am Fish Soc 127:275-285

Hall SJ (1994) Physical disturbance and marine benthic communities: life in unconsolidated sediments. Oceanogr Mar Biol Annu Rev 32:179-239

Hall SJ (1999) The effects of fishing on marine ecosystems and communities. Blackwell Science, London

Hare JA, Cowen RK (1996) Transport mechanisms of larval and pelagic juvenile bluefish (Pomatomus saltatrix) from South Atlantic Bight spawning grounds to Middle Atlantic Bight nursery areas. Limnol Oceanogr 41:1264-1280

Hewitt JE, Thrush SE, Cummings VJ (2001) Assessing environmental impacts: effects of spatial and temporal variability at likely impact scales. Ecol Appl 11:1502-1516

Houghton RW, Schlitz R, Beardsley RC, Butman B, Lockwood Chamberlin J (1982) The Middle Atlantic Bight cold pool: evolution of the temperature structure during summer 1979. J Phys Oceanogr 12:1019-1029

Hurlbert SJ (1984) Pseudoreplication and the design of ecological field experiments. Ecol Monogr 54:187-211

Jennings S, Kaiser MJ (1998) The effects of fishing on marine ecosystems. Adv Mar Biol 34:201-352

Jonsson IG (1966) Wave boundary layers and other friction factors. Proc 10th Conf Coastal Eng, Am Soc Civ Eng 1: 127-148

Kaiser MJ, Spencer BE (1994) Fish scavenging behavior in recently trawled areas. Mar Ecol Prog Ser 112:41-49

Kaiser MJ, Spencer BE (1996) The effects of beam-trawl disturbance on infaunal communities in different habitats. J Anim Ecol 65:348-358

Kaiser MJ, Edwards DB, Armstrong PJ, Radford K, Lough NEL, Flatt RP, Jones HD (1998) Changes in megafaunal benthic communities in different habitats after trawling disturbance. ICES J Mar Sci 55:353-361

Kaiser MJ, Ramsay K, Richardson CA, Spence FE, Brand AR (2000) Chronic fishing disturbance has changed shelf sea benthic community structure. J Anim Ecol 69:494-503

Komar PD, Neudeck RH, Kulm LD (1972) Observations and significance of deep-water oscillatory ripple marks on the Oregon continental shelf. In: Swift DJP, Duane DB, Pilkey $\mathrm{OH}$ (eds) Shelf sediment transport: process and pattern. Dowden, Hutchinson and Ross, Stroudsburg, PA, p 601-620

Kulbicki M (1998) How the acquired behaviour of commercial reef fishes may influence the results obtained from visual censuses. J Exp Mar Biol Ecol 222:11-30

Langton RW, Auster PJ, Schneider DC (1995) A spatial and temporal perspective on research and management of groundfish in the northwest Atlantic. Rev Fish Sci 3: 201-229

Levin SA (1992) The problem of pattern and scale in ecology. Ecology 73:1943-1967

Lindegarth M, Valentinsson D, Hansson M, Ulmestrand M 
(2000) Interpreting large-scale experiments on effects of trawling on benthic fauna: an empirical test of the potential effects of spatial confounding in experiments without replicated control and trawled areas. J Exp Mar Biol Ecol 245(2):155-169

Lindholm JB, Auster PJ, Kaufman LS (1999) Habitat-mediated survivorship of juvenile (0-year) Atlantic cod Gadus morhua. Mar Ecol Prog Ser 180:247-255

MacCall A (1990) Dynamic geography of marine fish populations. University of Washington Press, Seattle

Madsen OS, Grant WD (1975) The threshold of sediment movement under oscillatory water wave: a discussion. J Sediment Petrol 45:360-361

McConnaughey RA, Mier KL, Dew CB (2000) An examination of chronic trawling effects on soft-bottom benthos of the eastern Bering Sea. ICES J Mar Sci 57:1377-1388

Mullin MM (1993) Webs and scales: physical and ecological processes in marine fish recruitment. Washington Sea Grant Program, University of Washington Press, Seattle

Murawski SA, Serchuk FM (1989) Environmental effects of offshore dredge fisheries for bivalves. ICES 1989 Satutory Meeting. The Hague, Netherlands

NEFSC (Northeast Region Essential Fish Habitat Steering Committee) (2002) Workshop on the effects of fishing gear on marine habitats off the Northeastern United States. October 23-25, 2001, Boston, Massachusetts. Northeast Fish Sci Cent Ref Doc 02-01, Woods Hole, MA

Nelson JR, Eckman JE, Robertson CY, Marinelli RL, Jahnke RA (1999) Benthic microalgal biomass and irradiance at the sea floor on the continental shelf of the South Atlantic Bight: spatial and temporal variability and storm effects. Cont Shelf Res 19:477-505

Pile AJ, Lipcius RN, Van Montfrans J, Orth RJ (1996) Densitydependent settler-recruit-juvenile relationships in blue crabs. Ecol Monogr 66:277-300

Ramsay K, Kaiser MJ, Hughes RN (1998) Responses of benthic scavengers to fishing disturbance by towed gears in different habitats. J Exp Mar Biol Ecol 224:73-89

Schratzberger M, Dinmore TA, Jennings S (2002) Impacts of trawling on the diversity, biomass and structure of meiofauna assemblages. Mar Biol 140:83-93

Sissenwine MP (1984) Why do fish populations vary? In: May RM (ed) Exploitation of marine communities. SpringerVerlag, New York, p 59-95

Sokal RR, Rohlf FJ (1995) Biometry, 3rd edn. WH Freeman, New York

Steves BP, Cowen RK (2000) Settlement, growth, and movement of silver hake, Merluccius bilinearis, in nursery habitat on the New York Bight continental shelf. Mar Ecol Prog Ser 196:279-290

Steves BP, Cowen RK, Malchoff MH (2000) Settlement and nursery habitats for demersal fishes on the continental shelf of the New York Bight. Fish Bull 98:167-188

Editorial responsibility: Kenneth Sherman (Contributing Editor), Narragansett, Rhode Island, USA
Stoner AW, Mehta N, Lee TN (1997) Recruitment of Strombus veligers to the Florida Keys reef tract: relation to hydrographic events. J Shellfish Res 16:1-6

Sullivan MC, Cowen RK, Able KW, Fahay MP (2000) Spatial scaling of recruitment in four continental shelf fishes. Mar Ecol Prog Ser 207:141-154

Thompson AA, Mapstone BD (1997) Observer effects and training in underwater visual surveys of reef fishes. Mar Ecol Prog Ser 154:53-63

Thrush SF, Hewitt JE, Cummings VJ, Dayton PK and 6 others (1998) Disturbance of the marine benthic habitat by commercial fishing: impacts at the scale of the fishery. Ecol Appl 8:866-879

Tupper M, Boutilier RG (1995) Effects of habitat on settlement, growth, and postsettlement survival of Atlantic cod (Gadus morhua). Can J Fish Aquat Sci 52:1834-1841

Turner MG, Romme WH, Gardner RH, O'Neill RV, Kratz TK (1993) A revised concept of landscape equilibrium - disturbance and stability on scaled landscapes. Landscape Ecol 8:213-227

Underwood AJ (1991) Beyond BACI: experimental designs for detecting human environmental impacts on temporal variations in natural populations. Aust J Mar Freshw Res 42: 569-587

Underwood AJ (1993) The mechanics of spatially replicated sampling programmes to detect environmental impacts in a variable world. Aust J Ecol 18:99-116

Underwood AJ (1999) Physical disturbance and their direct effect on an indirect effect: responses of an intertidal assemblage to a severe storm. 232:125-140

Underwood AJ (2000) Importance of experimental design in detecting and measuring stresses in marine populations. J Aquat Ecosyst Stress Recov 7:3-24

USDOC (US Department of Commerce) (1996) MagnusonStevens Fishery Conservation and Management Act as amended through October 11, 1996. NOAA Technical Memorandum, NMFS-F/SPO-23

Vincent CE, Swift DJP, Hillard B (1981) Sediment transport in the New York Bight, North American Atlantic Shelf. Mar Geol 42:369-398

Wahle RA, Steneck RS (1991) Recruitment habitats and nursery grounds of the American lobster Homarus americanus: A demographic bottleneck? Mar Ecol Prog Ser 69:231-243

Watling L, Norse EA (1998) Disturbance of the seabed by mobile fishing gear: a comparison to forest clearcutting. Conserv Biol 12:1180-1197

Watling L, Findlay RH, Mayer LM, Schick DF (2001) Impact of a scallop drag on the sediment chemistry, microbiota, and faunal assemblages of a shallow subtidal marine benthic community. J Sea Res 46:309-324

Weissburg MJ, Zimmer-Faust RK (1993) Life and death in moving fluids: hydrodynamic effects on chemosensorymediated predation. Ecology 74:1428-1443

Submitted: October 22, 2002; Accepted: April 23, 2003

Proofs received from author(s): September 4, 2003 